Research Article

\title{
ASSESSMENT OF DISEASE RESISTANCE AND HIGH YIELDING TRAITS OF COMMON BUCKWHEAT GENOTYPES IN SUBTROPICAL CLIMATE OF NEPAL
}

\author{
S. Subedi ${ }^{1 *}$, N.B. Dhami ${ }^{2}$, S.B. Gurung ${ }^{2}$, S. Neupane ${ }^{1}$, S. Thapa ${ }^{1}$ and L. Oli ${ }^{1}$ \\ ${ }^{1}$ National Maize Research Program, Rampur, Chitwan \\ ${ }^{2}$ Hill Crops Research Program, Kabre, Dolakha
}

\begin{abstract}
Twelve common buckwheat (Fagopyrum esculentum Moench) genotypes received from Hill Crops Research Program, Kabre, Dolakha were evaluated for resistance against major foliar fungal diseases and high yielding traits at the research field of National Maize Research Program, Rampur, Chitwan during winter seasons of two consecutive years 2017 and 2018. The design of the experiment was Randomized Complete Block having three replications. The unit plot size was $3 \mathrm{~m} x$ $2 \mathrm{~m}$ with $25 \mathrm{~cm}$ row to row spacing and continues plant to plant spacing was maintained and net harvested plot was $6 \mathrm{sq}$ meters. The experiment was planted at last week of October in both years. The recommended dose of fertilizer was 30:30:0 for N:P:K kg ha ${ }^{-1}$ respectively and seed rate $50 \mathrm{~kg} \mathrm{ha}^{-1}$. Disease data were recorded for downy mildew (Perenospora fagopyri), powdery mildew (Erysiphepolygoni) and botrytis leaf blight (Botrytis cinerea) severity on 20 randomly tagged plants/plot. The yield and yield attributing traits were recorded. Buckwheat genotypes differed significantly $(p<0.05)$ on disease severity, grain yield and yield attributing traits. Genotypes CBBP-01, KIF-72-22-520, GF5283, ACC\#2234 and ACC\#2213 were resistant to powdery mildew, downy mildew and botrytis leaf blight and also resulted in higher grain yield. Grain yield had found strong negative correlation with the fungal disease severity of buckwheat. These genotypes might be useful for the development of major foliar fungal disease resistant high yielding common buckwheat variety in inner terai region of Nepal.
\end{abstract}

Keywords: buckwheat, Disease resistance, Genotypes, Yielding traits

\section{INTRODUCTION}

Common or sweet buckwheat (Fagopyrum esculentum Moench) and bitter buckwheat (Fagopyrum tataricum (L.) Gaertn) both belongs to family Polygonacea.

\footnotetext{
*Corresponding author: subedi.subash1@ gmail.com
} 
Globally 18 species are known to be the members of genus Fagopyrum including two cultivated species Fagopyrum esculentum and F. tataricum (Oshaki et al., 2001). It is a sixth staple food crop next to rice, wheat, maize, finger millet, and barley in term of cultivation area (10296 ha), production $(11472 \mathrm{mt})$ and yield $\left(1114 \mathrm{~kg} \mathrm{ha}^{-1}\right)$ in Nepal (MoAD, 2019). It is considered as a pseudo-cereal, poor man's crop, and underexploited or neglected crops, occupying major place for Nepalese agriculture system and contributing greatly in food and nutrition security of remote areas especially in high hilly regions (Baniya, 1995).It is the best crop in higher altitude in terms of adaptation to different climatic variables and easily fitted to different cropping patterns due to short duration (Joshi, 2008). It is cultivated on marginal land in 61 out of 75 districts of Nepal from about 60 to 4500 masl, especially hilly and mountain districts. Sweet or common buckwheat varieties are generally grown in mid hill, terai and inner terai region but Tartary or bitter buckwheat varieties are grown in higher altitude (Baral et al., 2014). There are altogether 19 local landraces of sweat or common buckwheat and 37 for Tartary or bitter buckwheat listed from Nepal (Joshi, 2008). Although the scope and demand of buckwheat is increasing due to its medicinal and nutritional values but the yield potential is reducing due to several biotic and abiotic constraints. The reason behind the low productivity of most of the crops in Nepal is due to the attack of many plant diseases at different stages of crop. Disease is one of the major biotic constraints to reduce buckwheat yield and also deteriorate the quality of product that ultimately reduce the market price. Buckwheat plants are affected by wide range of pathogens with fungal diseases being the most important. Fungal diseases decrease in productivity through infection and damage to leaves, stems, roots and pods as well as reduce market value due to discolor seeds (Subedi et al., 2015). Among biotic constraints, downy mildew (Perenospora fagopyri), powdery mildew (Erysiphe polygoni), botrytis leaf blight (Botrytis cinerea), rust (Puccinia fagopyri), damping-off and root rot (Rhizocto niasolani, Pythium spp, Fusariumspp) were the major fungal diseases contributes the wide yield gap in buckwheat genotypes (Manandhar et al., 2016). Resistant varieties provide a more effective and more consistent method of disease control without causing any hazards to environment. Transfer of available resistance traits in a cultivated background is especially important for farmers lacking resources to control the disease (Subedi, 2015). Therefore, the present study was undertaken in order to find out the resistant/tolerant buckwheat genotypes against major foliar diseases and the direct and indirect contributions of these traits toward yield.

\section{MATERIALS AND METHODS}

Twelve buckwheat genotypes received from Hill Crops Research Program (HCRP), Kavre, Dolakha were evaluated for sources of disease resistance and yield related traits in National Maize Research Program (NMRP), Rampur, Chitwan during winter seasons of two consecutive years 2017 and 2018. The geographical location of the research area was $27^{\circ} 37^{\prime} \mathrm{N}$ latitude and $84^{\circ} 25^{\prime} \mathrm{E}$ longitude at an altitude of 256 
ABMSL and has sub-tropical climate. The design of the experiment was randomized complete block having three replications. The unit plot size was $3 \mathrm{~m}$ x $2 \mathrm{~m}$ with $25 \mathrm{~cm}$ row to row spacing and continues plant to plant spacing was maintained and net harvested plot was 6 square meters. The experiment was planted at last week of October in both years. The recommended dose of fertilizer was 30:30:0 N:P:K kg ha-1 and seed rate $50 \mathrm{~kg} \mathrm{ha}^{-1}$. Other agronomic practices were followed as recommended (HCRP, 2017). Disease data were recorded for downy mildew (Perenosporafagopyri) and powdery mildew (Erysiphe polygoni) severity in 0-9 scale (Manandhar et al., 2016) whereas botrytis leaf blight (Botrytis cinerea) severity in 1-9 scoring scale on 20 randomly tagged plants/plot (Morrall and Mckenzie, 1974). Yield and yield attributing traits like days to flowering, days to maturity, plant height $(\mathrm{cm})$, grain yield $\left(\mathrm{kg} \mathrm{ha}^{-1}\right)$ and hundred seed weight $(\mathrm{g})$ were recorded. Percent Disease Index (PDI) is computed on the basis of recorded data according to the formula (Wheeler, 1969).

$\operatorname{PDI}(\%)=\frac{\text { Sum of all numerical values }}{\text { No of plants observed }} \times \frac{100}{\text { Maximum diseases rating }}$

All data were analyzed statistically using Microsoft Excel and MSTAT-C computer package program. Treatment means were compared using duncans multiple range test (DMRT) at 5\% level of significance $(\mathrm{P} \leq 0.05)$. The relationship between disease severity and yield were also calculated.

\section{RESULTS AND DISCUSSION}

\section{Experiment during 2017}

Data revealed that statistically significant differences were observed in the traits flowering days, days to maturity, plant height $(\mathrm{cm})$, grain yield $\left(\mathrm{kg} \mathrm{ha}^{-1}\right)$, hundred seed weight $(\mathrm{g})$, powdery mildew, downy mildew and botrytis leaf blight severity among buckwheat genotypes during winter season of 2017 (Table 1). The flowering days ranged from (19-25 days), maturity days (57-68 days), plant height $(96-106 \mathrm{~cm})$ and hundred seed weight $(3.30-4.20 \mathrm{~g})$. Buckwheat genotypes KIF-72-22-520 (1958.56 kg ha-1), CBBP-01 (1950 kg ha-1), GF 5283 (1868.44 kg ha-1), ACC\#2234 $\left(1857.22 \mathrm{~kg} \mathrm{ha}^{-1}\right)$ and PL $15\left(1850.44 \mathrm{~kg} \mathrm{ha}^{-1}\right)$ were the high yielding compare to standard check Mithe Phapar-1 (1830 kg ha $\left.{ }^{-1}\right)$.

Out of 12 buckwheat genotypes, CBBP-01, KIF-72-22-520, ACC\#2234, GF 5283, ACC\#2213 and PL-15 were resistant having percent disease index (PDI) of 26.35, $27.08,30.05,31.45,31.65$ and $32.25 \%$ respectively whereas Chitwan local (local check) was susceptible having PDI of $56.88 \%$ to powdery mildew disease. The downy mildew severity was found lower in genotypes KIF-72-22-520 (32.42\%), CBBP-01 (34.25\%), GF 5283 (35.58\%) and ACC\#2234 (38.45\%) compared to 
standard check Mithe Phapar-1 (41.45\%). The higher downy mildew severity was recorded in genotype ACC\#6529 $(65.92 \%)$ followed by Chitwan local (61.72\%).Similarly, botrytis leaf blight severity was found lower in genotypes CBBP-01 (37.45\%), KIF-72-22-520 (38.88\%), GF 5283 (41.35\%), ACC\#2234 (43.95\%) and ACC\#2213 (45.48\%) compared to standard check Mithe Phapar-1 $(48.58 \%)$. The higher botrytis leaf blight severity was recorded in genotype ACC\#6529 (73.35\%) followed by Chitwan local (66.58\%) (Table 1).

Table 1. Response of buckwheat genotypes to yield parameters and major foliar fungal diseases at NMRP, Rampur, Chitwan, Nepal during winter season of 2017

\begin{tabular}{|c|c|c|c|c|c|c|c|c|}
\hline \multirow{2}{*}{ enotypes } & \multirow{2}{*}{$\begin{array}{c}\mathrm{Fl}_{-} \\
\text {days }\end{array}$} & \multirow{2}{*}{$\begin{array}{c}\text { Mat_ } \\
\text { days }\end{array}$} & \multirow{2}{*}{$\begin{array}{l}\text { PHT } \\
(\mathrm{cm})\end{array}$} & \multirow{2}{*}{$\begin{array}{c}\mathrm{GY} \\
\left(\mathrm{kg} \mathrm{ha}^{-1}\right)\end{array}$} & \multirow{2}{*}{$\begin{array}{c}\text { HSWt } \\
(\mathrm{g})\end{array}$} & \multicolumn{3}{|c|}{ Percent disease index $(\%)$} \\
\hline & & & & & & $\mathrm{PM}$ & $\mathrm{DM}$ & BLB \\
\hline АCC\#5670 & $\dagger 23^{\mathrm{bc}}$ & $66^{\mathrm{abc}}$ & $96^{\mathrm{f}}$ & $1677.11^{\mathrm{d}}$ & $3.30^{\mathrm{f}}$ & $47.68^{\mathrm{c}}$ & $56.42^{\mathrm{c}}$ & $62.28^{\mathrm{c}}$ \\
\hline ACC\#2213 & $22^{c}$ & $64^{\text {cde }}$ & $99^{\mathrm{d}}$ & $1755.11^{\mathrm{c}}$ & $3.90^{\mathrm{bcd}}$ & $31.65^{\mathrm{d}}$ & $42.75^{\mathrm{d}}$ & $45.48^{\mathrm{f}}$ \\
\hline ACC\#6529 & $22^{\mathrm{c}}$ & $60^{\mathrm{f}}$ & $102^{\mathrm{cd}}$ & $1438.33^{\mathrm{e}}$ & $4.20^{\mathrm{a}}$ & $64.12^{\mathrm{a}}$ & $65.92^{\mathrm{a}}$ & $73.35^{\mathrm{a}}$ \\
\hline ACC\#2234 & $23^{\mathrm{bc}}$ & $63^{\mathrm{de}}$ & $101^{\text {cde }}$ & $1857.22^{b}$ & $4.10^{\mathrm{ab}}$ & $30.05^{\mathrm{d}}$ & $38.45^{\mathrm{e}}$ & $43.95^{\mathrm{f}}$ \\
\hline C-30 & $23^{\mathrm{bc}}$ & $65^{\mathrm{bcd}}$ & $101^{\text {cde }}$ & $1660.56^{\mathrm{d}}$ & $3.80^{\text {cde }}$ & $50.02^{\mathrm{c}}$ & $55.45^{\mathrm{c}}$ & $62.58^{\mathrm{c}}$ \\
\hline GF 5283 & $24^{\mathrm{abc}}$ & $68^{\mathrm{ab}}$ & $101^{\text {cde }}$ & $1868.44^{\mathrm{b}}$ & $3.50^{\mathrm{f}}$ & $31.45^{\mathrm{d}}$ & $35.58^{\mathrm{ef}}$ & $41.35^{\mathrm{g}}$ \\
\hline CBBP-01 & $19^{\mathrm{d}}$ & $61^{\mathrm{ef}}$ & $103^{\mathrm{bc}}$ & $1950.00^{\mathrm{a}}$ & $4.10^{\mathrm{ab}}$ & $26.35^{\mathrm{e}}$ & $34.25^{\mathrm{fg}}$ & $37.45^{\mathrm{h}}$ \\
\hline KIF- & $25^{\mathrm{a}}$ & $68^{\mathrm{a}}$ & $105^{\mathrm{ab}}$ & $1958.56^{\mathrm{a}}$ & $3.40^{\mathrm{f}}$ & $27.08^{\mathrm{e}}$ & & \\
\hline PL 15 & $25^{\mathrm{a}}$ & $67^{\mathrm{ab}}$ & $106^{\mathrm{a}}$ & $1850.44^{\mathrm{b}}$ & $4.10^{\mathrm{ab}}$ & $32.25^{\mathrm{d}}$ & $42.62^{\mathrm{d}}$ & $55.42^{\mathrm{d}}$ \\
\hline ACC\#493 & $24^{\mathrm{abc}}$ & $66^{\mathrm{abc}}$ & $101^{\text {cde }}$ & $1463.33^{\mathrm{e}}$ & $3.80^{\text {cde }}$ & $55.32^{\mathrm{b}}$ & $58.22^{\mathrm{c}}$ & $64.38^{\mathrm{bc}}$ \\
\hline Mithe Phar & $22^{c}$ & $63^{\mathrm{de}}$ & $102^{\text {cd }}$ & $1830.00^{b}$ & $3.60^{\mathrm{ef}}$ & $32.52^{\mathrm{d}}$ & $41.45^{\mathrm{d}}$ & $48.58^{\mathrm{e}}$ \\
\hline Chitwan Loca & $19^{\mathrm{d}}$ & $57^{\mathrm{g}}$ & $97^{\mathrm{e}}$ & $1473.56^{\mathrm{e}}$ & $3.30^{\mathrm{f}}$ & $56.88^{\mathrm{b}}$ & $61.72^{\mathrm{b}}$ & $66.58^{\mathrm{b}}$ \\
\hline Grand mean & 22.58 & 64.06 & 101.08 & 1731.89 & 3.80 & 40.45 & 47.10 & 53.36 \\
\hline F test & $* *$ & $* *$ & $* *$ & $* *$ & $* *$ & $* *$ & $* *$ & $* *$ \\
\hline LSD $(0$. & 2.06 & 2.26 & 2.18 & 38.60 & 0.03 & 2.43 & 2.89 & 2.33 \\
\hline $\mathrm{CV}, \%$ & 5.40 & 2.10 & 1.30 & 1.30 & 4.00 & 3.50 & 3.60 & 2.60 \\
\hline
\end{tabular}

Note: $\uparrow$ Means of 3 replications, Means in column with same superscript is not significantly differed by DMRT $(\mathrm{P} \leq 0.05)$. Fl days - flowering days, Mat_days - maturity days, PHT- Plant height, GY - grain yield, HSWt- hundred seed weight, PM- Powdery mildew, DM- Downy mildew, BLB- Botrytis leaf blight, \%- percentage, cm-centimeter, $\mathrm{kg} \mathrm{ha}^{-1}$ - kilogram per hectare, g- gram, SC- standard check, LClocal check, $* *$ - highly significant

\section{Experiment during 2018}

During 2018 also, trends of both disease development, yield and yield attributing traits were similar. The yield $\left(\mathrm{kg} \mathrm{ha}^{-1}\right)$ and yield attributing traits like flowering days, 
days to maturity, plant height $(\mathrm{cm})$ and hundred seed weight $(\mathrm{g})$ were significantly varied with buckwheat genotypes (Table 2). The flowering days ranged from (22-29 days), maturity days (61-71 days), plant height $(100-108 \mathrm{~cm})$ and hundred seed weight (3.60 - $4.50 \mathrm{~g})$. Buckwheat genotypes CBBP-01 (2050 kg ha-1), KIF-72-22$520\left(2048.89 \mathrm{~kg} \mathrm{ha}^{-1}\right)$, GF $5283\left(1984.44 \mathrm{~kg} \mathrm{ha}^{-1}\right)$, ACC\#2234 (1953.89 kg ha $\left.{ }^{-1}\right)$ and ACC\#2213 (1952.78 $\mathrm{kg} \mathrm{ha}^{-1}$ ) were the high yielding compare to standard check Mithe Phapar-1 (1950 kg ha ${ }^{-1}$ ) (Table 2).

Table 2. Performance of buckwheat genotypes to yield parameters and major foliar fungal diseases at NMRP, Rampur, Chitwan, Nepal during winter season of 2018

\begin{tabular}{|c|c|c|c|c|c|c|c|c|}
\hline \multirow{2}{*}{ Genotypes } & \multirow{2}{*}{$\begin{array}{c}\mathrm{Fl}_{-} \\
\text {Days }\end{array}$} & \multirow{2}{*}{$\begin{array}{l}\text { Mat_ } \\
\text { days }\end{array}$} & \multirow{2}{*}{$\begin{array}{l}\text { PHT } \\
(\mathrm{cm})\end{array}$} & \multirow{2}{*}{$\begin{array}{c}\mathrm{GY} \\
\left(\mathrm{kg} \mathrm{ha}^{-1}\right)\end{array}$} & \multirow{2}{*}{$\begin{array}{l}\text { HSWt } \\
(\mathrm{g})\end{array}$} & \multicolumn{3}{|c|}{ Percent disease index $(\%)$} \\
\hline & & & & & & PM & $\mathrm{DM}$ & BLB \\
\hline ACC\#5670 & $\dagger 25^{\mathrm{d}}$ & $68^{\mathrm{bc}}$ & $100^{\mathrm{e}}$ & $1784.44^{\mathrm{c}}$ & $3.60^{\mathrm{d}}$ & $52.05^{\mathrm{d}}$ & $63.55^{\mathrm{b}}$ & $68.25^{\mathrm{c}}$ \\
\hline ACC\#2213 & $26^{\mathrm{cd}}$ & $67^{\mathrm{cd}}$ & $103^{\mathrm{cd}}$ & $1952.78^{\mathrm{b}}$ & $4.20^{\mathrm{b}}$ & $36.68^{\mathrm{ef}}$ & $46.35^{\mathrm{e}}$ & $54.28^{\mathrm{f}}$ \\
\hline ACC\#6529 & $25^{\mathrm{d}}$ & $63^{\mathrm{e}}$ & $105^{\mathrm{bc}}$ & $1526.67^{\mathrm{d}}$ & $4.60^{\mathrm{a}}$ & $67.48^{\mathrm{a}}$ & $69.38^{\mathrm{a}}$ & $75.72^{\mathrm{a}}$ \\
\hline ACC\#2234 & $27^{\mathrm{bc}}$ & $67^{\mathrm{cd}}$ & $103^{\mathrm{c}}$ & $1953.89^{\mathrm{b}}$ & $4.50^{\mathrm{a}}$ & $36.72^{\mathrm{ef}}$ & $43.78^{\mathrm{f}}$ & $51.45^{\mathrm{g}}$ \\
\hline PC-30 & $28^{\mathrm{ab}}$ & $70^{\mathrm{ab}}$ & $102^{\mathrm{cd}}$ & $1785.56^{\mathrm{c}}$ & $4.00^{\mathrm{bc}}$ & $51.38^{\mathrm{d}}$ & $61.48^{\mathrm{c}}$ & $65.28^{\mathrm{d}}$ \\
\hline GF 5283 & $26^{\mathrm{cd}}$ & $67^{\mathrm{cd}}$ & $101^{\mathrm{de}}$ & $1984.44^{\mathrm{ab}}$ & $4.00^{\mathrm{bc}}$ & $35.58^{\mathrm{f}}$ & $40.72^{\mathrm{g}}$ & $49.55^{\mathrm{g}}$ \\
\hline CBBP-01 & $23^{\mathrm{e}}$ & $63^{\mathrm{e}}$ & $106^{\mathrm{ab}}$ & $2050.00^{\mathrm{a}}$ & $4.20^{\mathrm{b}}$ & $30.05^{\mathrm{h}}$ & $35.62^{\mathrm{h}}$ & $40.58^{\mathrm{i}}$ \\
\hline KIF-72-22-520 & $29^{\mathrm{a}}$ & $71^{\mathrm{a}}$ & $108^{\mathrm{a}}$ & $2048.89^{\mathrm{a}}$ & $3.80^{\mathrm{cd}}$ & $33.45^{\mathrm{g}}$ & $39.08^{\mathrm{g}}$ & $46.22^{\mathrm{h}}$ \\
\hline PL 15 & $28^{\mathrm{ab}}$ & $69^{\mathrm{ab}}$ & $108^{\mathrm{a}}$ & $1949.11^{\mathrm{b}}$ & $4.20^{\mathrm{b}}$ & $37.38^{\mathrm{e}}$ & $49.42^{\mathrm{d}}$ & $56.38^{\mathrm{e}}$ \\
\hline ACC\#493 & $27^{\mathrm{bc}}$ & $69^{\mathrm{ab}}$ & $105^{\mathrm{b}}$ & $1550.00^{\mathrm{d}}$ & $4.10^{\mathrm{b}}$ & $65.45^{\mathrm{b}}$ & $69.18^{\mathrm{a}}$ & $72.42^{\mathrm{b}}$ \\
\hline Mithe Phapar-1 (SC) & $27^{\mathrm{bc}}$ & $66^{\mathrm{d}}$ & $103^{\mathrm{c}}$ & $1950.00^{\mathrm{b}}$ & $4.20^{\mathrm{b}}$ & $36.55^{\mathrm{ef}}$ & $47.55^{\mathrm{e}}$ & $55.62^{\mathrm{ef}}$ \\
\hline Chitwan Local (LC) & $22^{\mathrm{e}}$ & $61^{\mathrm{f}}$ & $100^{\mathrm{e}}$ & $1586.22^{\mathrm{d}}$ & $3.80^{\mathrm{cd}}$ & $62.48^{\mathrm{c}}$ & $64.72^{\mathrm{b}}$ & $71.42^{\mathrm{b}}$ \\
\hline Grand mean & 26.08 & 66.72 & 103.72 & 1843.50 & 4.10 & 45.44 & 52.57 & 58.93 \\
\hline F test & $* *$ & $* *$ & $* *$ & $* *$ & $* *$ & $* *$ & $* *$ & $* *$ \\
\hline $\operatorname{LSD}(0.05)$ & 1.38 & 1.74 & 1.61 & 64.60 & 0.03 & 1.50 & 1.86 & 1.93 \\
\hline $\mathrm{CV}, \%$ & 3.10 & 1.50 & 0.90 & 2.10 & 3.70 & 1.90 & 2.10 & 1.90 \\
\hline
\end{tabular}

Note: $\dagger$ Means of 3 replications, Means in column with same superscript is not significantly differed by DMRT $(\mathrm{P} \leq 0.05)$. Fl_days - flowering days, Mat_days - maturity days, PHT- Plant height, GY- grain yield, HSWt- hundred seed weight, PM- Powdery mildew, DM- Downy mildew, BLB- Botrytis leaf blight, \%- percentage, $\mathrm{cm}$-centimeter, $\mathrm{kg} \mathrm{ha}^{-1}$ - kilogram per hectare, g- gram, SC- standard check, LClocal check, $* *$ - highly significant

Genotypes, CBBP-01, KIF-72-22-520, GF 5283, ACC\#2213 and ACC\#2234 were resistant having percent disease index (PDI) of 30.05, 33.45, 35.58, 36.68 and $36.72 \%$ respectively compared to standard check Mithe Phapar-1 (36.55\%) whereas ACC\#6529, ACC\#493 and Chitwan local (local check) was susceptible having PDI of $67.48,65.45$ and $62.48 \%$ respectively to powdery mildew disease. The downy 
mildew severity was found lower in genotypes CBBP-01 (35.62\%), KIF-72-22-520 (39.08\%), GF 5283 (40.72\%) and ACC\#2234 (43.78\%) and ACC\#2213 (46.35\%) compared to standard check Mithe Phapar-1 (47.55\%) (Table 2). The higher downy mildew severity was recorded in genotype ACC\#6529 (69.38\%) followed by ACC\#493 (69.18\%) and Chitwan local (64.72\%). Similarly, botrytis leaf blight severity was found lower in genotypes CBBP-01 (40.58\%), KIF-72-22-520 (46.22\%), GF 5283 (49.55\%), ACC\#2234 (51.45\%) and ACC\#2213 (54.28\%) compared to standard check Mithe Phapar-1 (55.62\%). The higher botrytis leaf blight severity was recorded in genotype ACC\#6529 (75.72\%) followed by ACC\# 493 $(72.42 \%)$ and Chitwan local (71.42\%) (Table 2).

\section{Relationship between grain yield $\left(\mathrm{kg} \mathrm{ha}^{-1}\right)$ and powdery mildew severity (\%)}

During 2017-2018 cropping season of buckwheat, yield was found to had highly significant negative correlation $(r=-0.99)$ with the percent disease index of powdery mildew disease. The predicted linear regression line was also displayed downward slope i.e. $y=-0.07 x+167.46$, with regression coefficient $R^{2}=0.97$, where ' $y$ ' denoted predicted crop yield of buckwheat and ' $x$ ' stood for PDI of powdery mildew of buckwheat (Fig. 1). The estimated regression line indicated that the unit rise in the PDI of powdery mildew disease (within 0-9 scale), there existed possibilities of yield reduction by $167.39 \mathrm{~kg} \mathrm{ha}^{-1}$.

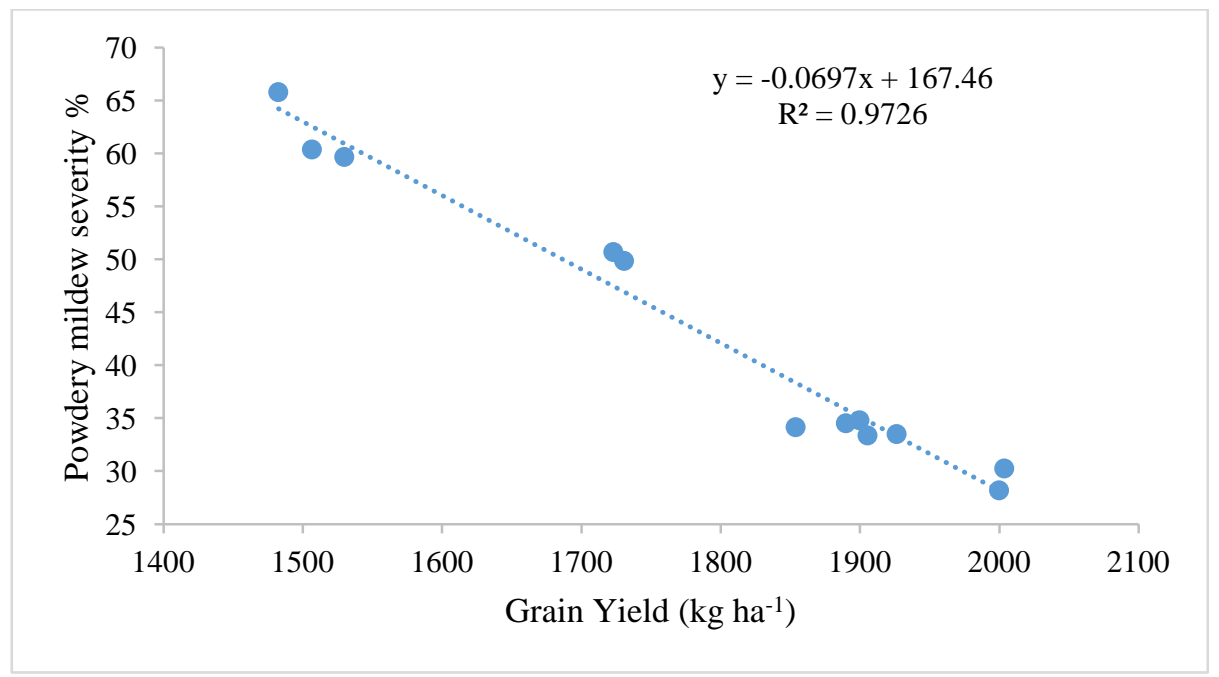

Figure 1. Relationship between crop yield $\left(\mathrm{kg} \mathrm{ha}^{-1}\right)$ and PDI of buckwheat powdery mildew at Rampur, Chitwan, Nepal during 2017-2018

\section{Relationship between grain yield $\left(\mathrm{kg} \mathrm{ha}^{-1}\right)$ and Downy mildew severity (\%)}

A significant linear negative correlation $(r=-0.96)$ between yield and downy mildew severity was observed representing the best fit having $\mathrm{R}^{2}=92 \%$ (Fig. 2). Obviously 
the yield decreased with the increase in Percent Disease Index (PDI). The predicted linear regression line was also displayed downward slope i.e. $y=-0.06 x+158$, with regression coefficient $\mathrm{R}^{2}=0.93$, where ' $\mathrm{y}$ ' denoted predicted crop yield of buckwheat genotypes and ' $x$ ' stood for PDI of downy mildew of buckwheat (Fig. 2). The estimated regression line indicated that the unit rise in the PDI of downy mildew disease (within 0-9 scale), there existed possibilities of yield reduction by 157.94 $\mathrm{kg} \mathrm{ha}^{-1}$.

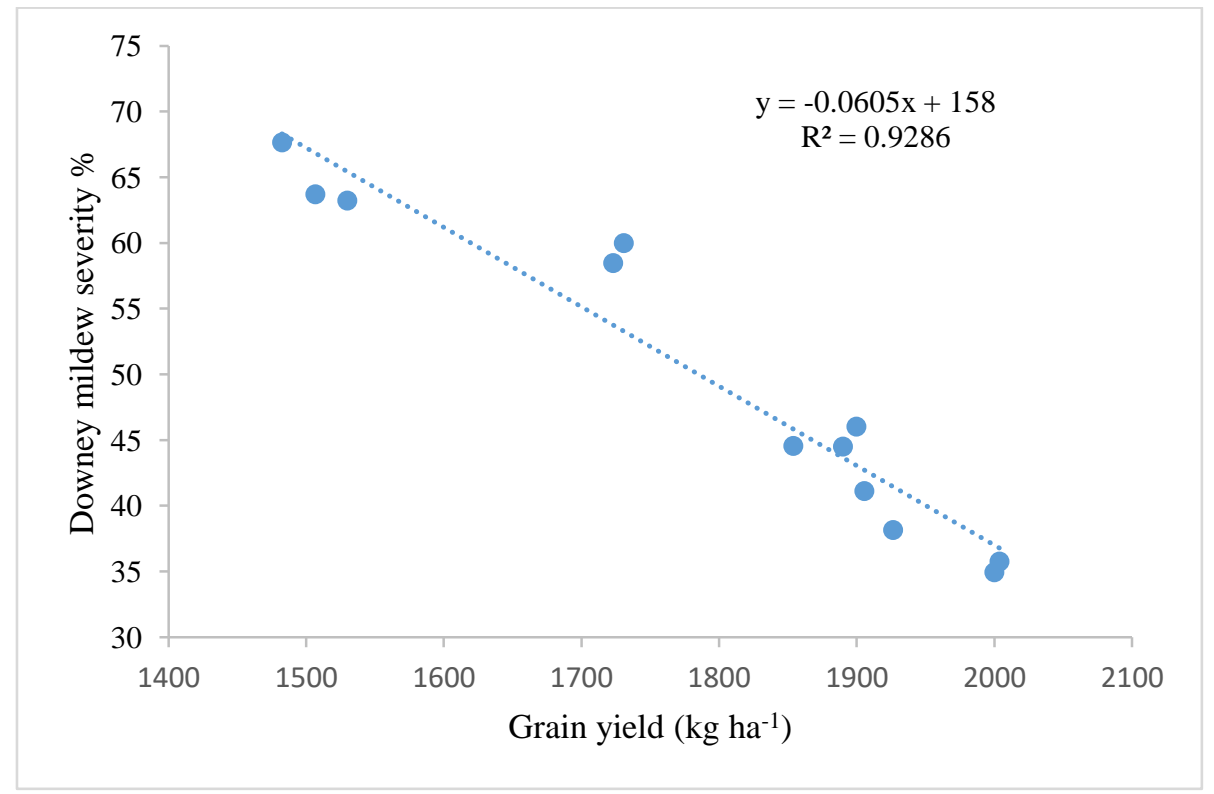

Figure 2. Relationship between crop yield $\left(\mathrm{kg} \mathrm{ha}^{-1}\right)$ and PDI of buckwheat downy mildew at Rampur, Chitwan, Nepal during 2017-2018

\section{Relationship between grain yield $\left(\mathrm{kg} \mathrm{ha}^{-1}\right)$ and botrytis leaf blight severity (\%)}

A linear negative correlation $(\mathrm{r}=-0.95)$ between yield and botrytis leaf blight severity was observed representing the best fit having $\mathrm{R}^{2}=89 \%$ (Figure 3 ). Obviously the yield decreased with the increase in Percent Disease Index (PDI). The predicted linear regression line was also displayed downward slope i.e. y = $0.06 x+160.73$, with regression coefficient $R^{2}=0.90$, where ' $y$ ' denoted predicted crop yield of buckwheat genotypes and ' $\mathrm{x}$ ' stood for PDI of botrytis leaf blight of buckwheat (Fig. 3). The estimated regression line indicated that the unit rise in the PDI of botrytis leaf blight disease (within 1-9 scale), there existed possibilities of yield reduction by $160.67 \mathrm{~kg} \mathrm{ha}^{-1}$. 


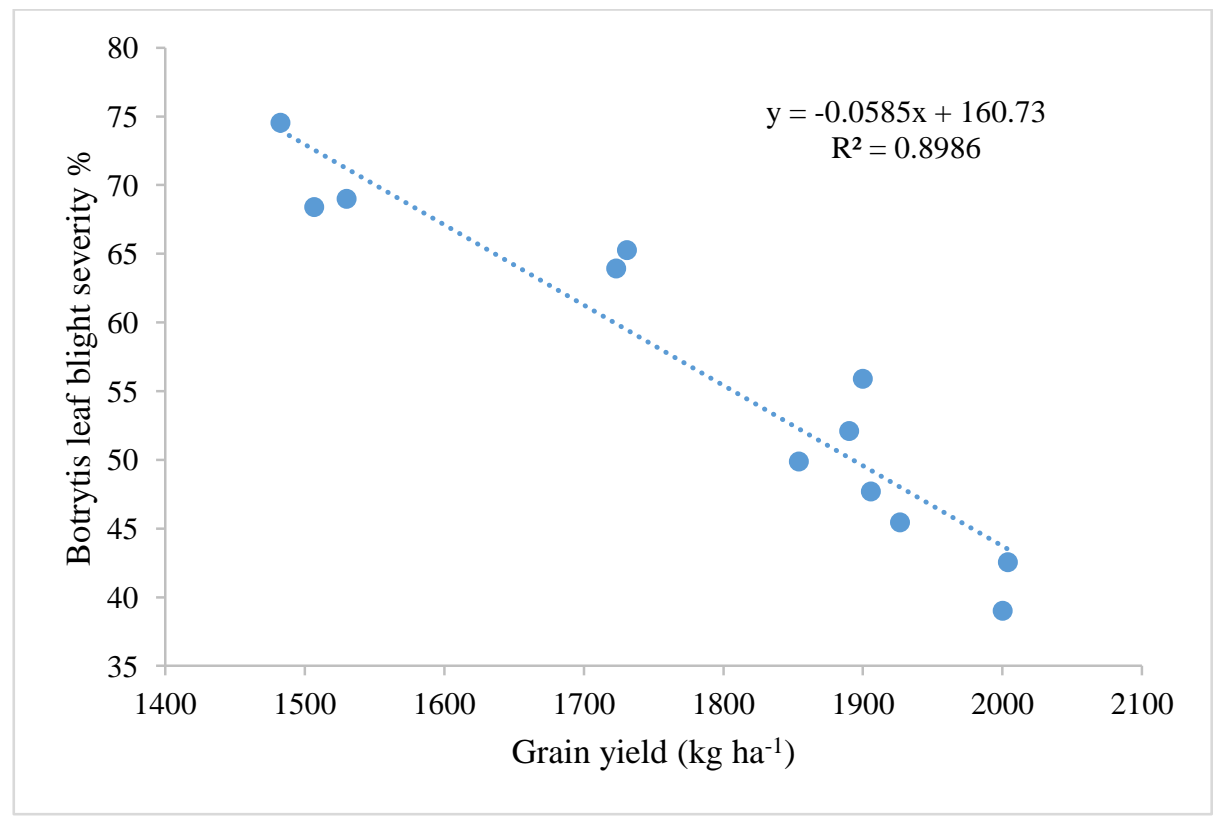

Figure 3. Relationship between yield $\left(\mathrm{kg} \mathrm{ha}^{-1}\right)$ and PDI of buckwheat botrytis leaf blight at Rampur, Chitwan, Nepal during 2017-2018

The genetic improvement of buckwheat is an important area to determine its potential for production and rapid distribution. Disease resistance has been found quite useful for the improvement of desired traits and addressing the productivity and yield related problems in buckwheat (Luitel et al., 2017). Even within a species of plant that is susceptible to a particular species of pathogen however there is considerable variation in both the susceptibility of the various plant cultivars towards the pathogen and the virulence of the various pathogen races toward the plant variety. The genetics of such host-pathogen interaction are of considerable biological interest and of the utmost importance in developing disease control strategies through breeding for resistance (Agrios, 2005). Although buckwheat is normally a cold tolerant and is not attacked by many diseases or pests but a number of diseases and pests have been reported on this crop (Joshi and Paroda, 1991). The major diseases are powdery mildew (Erysiphe polygoni), downy mildew (Peronospora ducumeti), stem rot (Botrytis cinerea), chlorotic leaf spot (Alternaria alternata), leaf spot (Septoria polygonicola), smut (Sphacelothecaj agopyri),root and stem rot (Phytophthoraj agopyri), brown leaf spot (Ascochyta italica), rust (Puccinia jagopyri), root and collar rot (Sclerotinia libertianai) and root rot (Fusarium spp.). Attacks of several viruses also cause reduction in plant height and losses in grain yield. From this experiment, buckwheat genotypes CBBP-01, KIF-72-22-520, GF5283, ACC\#2234 and ACC\# 2213 showed higher yield with lower foliar fungal disease severity. The findings of this experiment is in agreement with the Baniya et al. (1995) who 
reported that out of 309 common buckwheat landraces, days to 50\% flowering varied from 26 to 45 while days to $95 \%$ maturity varied from 67 to 98 . Plant height ranged from 25 to $116.4 \mathrm{~cm}$. There was a large variation noted in thousand grain weight from 10.2 to $31.8 \mathrm{~g}$. The ratings for disease were from no disease to $100 \%$ infection for powdery mildew and from no disease to $60 \%$ infection for downy mildew showing a wide variation that could be utilized in crop improvement programmes. The experiment conducted by Baral et al. (2014) showed that buckwheat genotypes T-Vaskar (1282 kg ha-1), GF $5289\left(1205 \mathrm{~kg} \mathrm{ha}^{-1}\right)$ and IR-13 (1212 $\left.\mathrm{kg} \mathrm{ha}^{-1}\right)$ as promising lines in the year 2012. Baniya et al. (1995) also reported that two main buckwheat diseases powdery mildew and downy mildew show negative correlation with yield and yield attributing traits indicating low incidence of disease is associated with high values of each respective trait. The resistance in buckwheat genotypes to different fungal diseases could be the presence of phenolic and flavonoids compounds like flavonols, anthocyanins and C-glucosyl-flavones (Mikulajova et al., 2016).

\section{CONCLUSION}

Grain yield had strong negative correlation with the major foliar fungal disease severity of buckwheat. Genotypes CBBP-01, KIF-72-22-520, GF5283, ACC\#2234 and ACC\# 2213 were resistant to powdery mildew, downy mildew and botrytis leaf blight that resulted in higher grain yield. The study can be useful for selecting suitable genotypes for the development of major foliar fungal disease resistant high yielding common buckwheat variety in subtropical climate of Nepal.

\section{ACKNOWLEDGEMENTS}

The fund for this study was achieved from Nepal Agricultural Research Council (NARC). Acknowledgements go to both NMRP and HCRP team and other technical staffs of NARC for their valuable suggestions, continuous support and facilities during experimentation period.

\section{REFERENCES}

Agrios, G.N. (2005). Plant Pathology, 5th ed. Elsevier Academic Press.30 Corporate Drive, Suite 400, Burlington, MA 01803, USA. Pp. 922.

Baniya, B.K. (1995). Present status of buckwheat genetic resources in Nepal. In T. Matano and A. Ujihara (Eds.). Proceedings of International Symposium on Buckwheat Current Advances in Buckwheat Research, $6^{\text {th }}$, Vol. I-III. 24-29 August, 1995. Shinshu University Press, Sinshu. Pp. 47-53.

Baniya, B.K., Dongol, D.M.S. and Dhungel, N.R. (1995). Further characterization and evaluation of Nepalese buckwheat (Fagopyrum spp.) landraces. In T. Matano and A. Ujihara (Eds.). Proceedings of International Symposium on Buckwheat - Current Advances in Buckwheat Research, 6 ${ }^{\text {th }}$, Vol. I-III. 24-29 August, 1995.Shinshu University Press, Sinshu. Pp. 295-304. 
Baral, K., Koirala, K.B., Subedi, S., Pokharel, A., Dhakal, J., KC, G., Paudel, A.P., Timilsina, A., Prasai, H.K. and Pokharel, B.B. (2014). Varietal investigation on buckwheat under different agro-ecological zones of Nepal. In Y.P. Giri, Y.G. Khadka, B.N. Mahato, B.P. Sah, S.P. Khatiwada, M.R. Bhatta, B.K. Chettri, A.K. Gautam, D. Gauchan, A.R. Ansari, J.D. Ranjit, R. Shrestha and B. Sapkota (Eds.). Proceedings of National Summer Crops Workshop, 27 ${ }^{\text {th }}$, Vol. 2. 18-20April, 2013. National Maize Research Program, Rampur, Chitwan, Nepal. Pp. 168-172.

HCRP. (2017). Annual Report 2073/74 (2016/17). Hill Crops Research Program, NARC, Kabre, Dolakha, Nepal. Pp. 131.

Joshi, B.K. (2008). Buckwheat genetic resources: status and prospects in Nepal. Agriculture Development Journal, 5:13-30.

Joshi, B.D. and Paroda, R.S. (1991). Buckwheat in India. National Bureau of Plant Genetic Resources, New Delhi, India. Pp. 117.

Luitel, D.R., Siwakoti, M., Jha, P.K., Jha, A.K. and Krakauer, N. (2017). An overview: distribution, production and diversity of local landraces of buckwheat in Nepal. Advances in Agriculture, 2017: 2738045.

Manandhar, H.K., Timila, R.D., Sharma, S., Joshi, S., Manandhar, S., Gurung, S.B., Sthapit, S., Palikhey, E., Pandey, A., Joshi, B.K., Manandhar, G., Gauchan, D., Jarvis, D.I. and Sthapit, B.R. (2016). A Field Guide for Identification and Scoring Methods of Diseases in the Mountain Crops of Nepal. NARC, DoA, LI-BIRD and Bioversity International, Nepal. Pp. 183.

Mikulajová, A., Šedivá, D., Hybenová, E. and Mošovská, S. (2016). Buckwheat cultivars phenolic compounds profiles and antioxidant properties. Acta Chimica Slovaca, 9 (2): 124-129.

MOAD. (2019). Statistical Information on Nepalese Agriculture 2017/18. Agri-Business Promotion and Statistics Division, Ministry of Agriculture Development, Kathmandu, Nepal. Pp. 290.

Morrall, R.A.A. and Mckenzie, D.L. (1974). A note on the inadvertent introduction to North America of Ascochytarabiei, a destructive pathogen of chickpea. Plant Disease reporter, 58:342-345.

Ohsaki, T., Fukuoka, S., Bimb, H.P., Baniya, B.K., Yasui, Y. and Ohnishi O. (2001). Phylogenetic analysis of the genus Fagopyrum (Polygonaceae), including the Nepali species $F$. megacarpum, based on nucleotide sequence of the rbcL-accD region in chloroplast DNA. Fagopyrum, 18: 9-14.

Subedi, S. (2015). A review on important maize diseases and their management in Nepal. Journal of Maize Research and Development, 1(1): 28-52.

Subedi, S., Gharti, D.B., Neupane, S., and Ghimire, T.N. (2015). Management of anthracnose in soybean using fungicide. Journal of Nepal Agricultural Research Council, 1:29-32.

Wheeler, B.E.J. (1969). An Introduction to Plant Diseases. John Wiley and Sons. Ltd. London, UK. Pp. 301. 